\title{
Metabolsk syndrom i Sri Lanka
}

\section{Metabolsk syndrom er svært vanlig i Sri Lanka og opptrer hyppigere hos kvinner enn hos menn. Det viser funn fra en nylig publisert studie.}

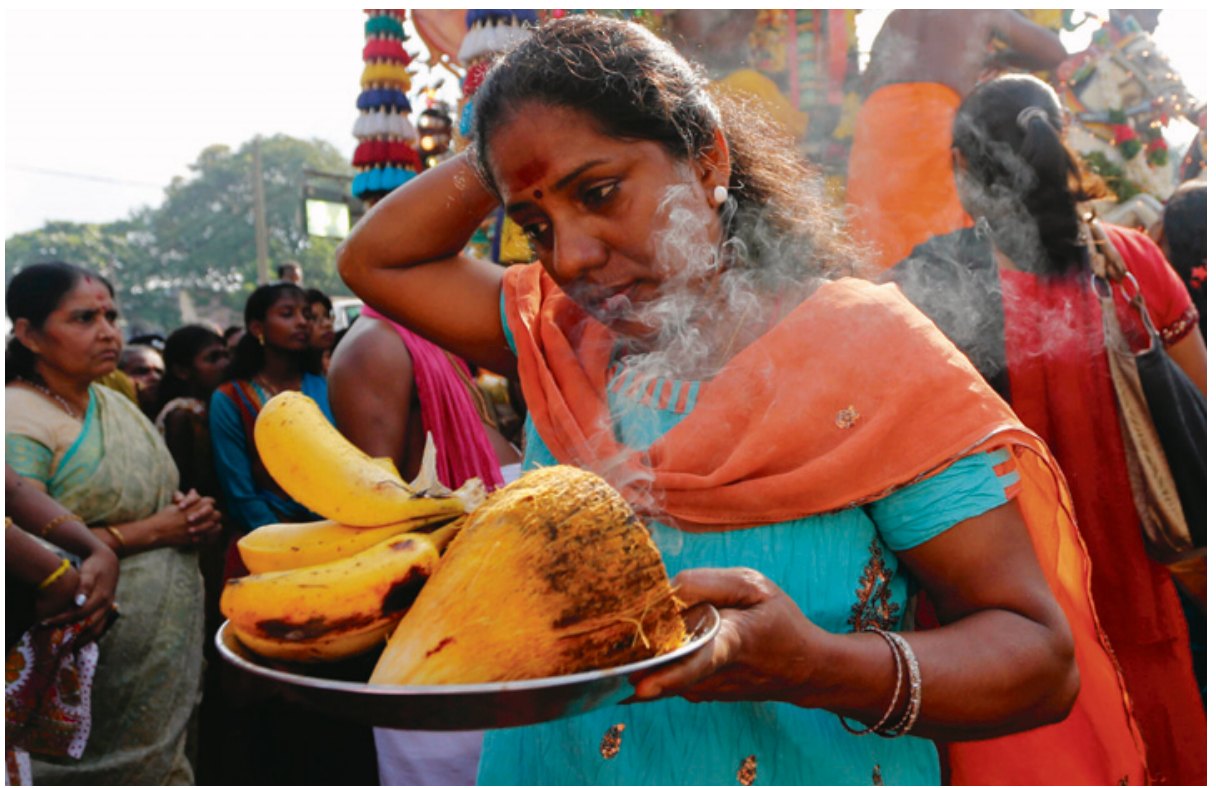

Illustrasjonsfoto Eranga Jayawardena/Ap/NTB scanpix

Ifølge tidligere forskning er metabolsk syndrom vanligere blant sørasiatiske innvandrere i USA sammenliknet med opprinnelige kaukasiere. Det er imidlertid få representative undersøkelser på forekomsten i sørasiatiske land.

Studien fra Sri Lanka beskriver utbredelsen av metabolsk syndrom i den voksne srilankiske befolkning. I den populasjonsbaserte tverrsnittsunders $\emptyset$ kelsen med 4485 deltakere, og en responsrate på $89,7 \%$, blir forekomsten sammenholdt med sosiodemografiske, kliniske og biokjemiske parametre (1).

Metabolsk syndrom ble definert i henhold til kriteriene i International Diabetes Federation. Syndromet var hyppigere hos kvinner $(28,3 \%)$ enn hos menn $(18,4 \%)$. Videre var det flere i den urbane befolkningen som hadde det sammenliknet med folk på lands-

\section{Når skal traume- teamet aktiveres?}

\author{
Traumeteamet skal stå klart \\ og jobbe effektivt når pasienten \\ kommer til sykehuset. Da må \\ teamet aktiveres 10-20 minutter \\ før pasienten ankommer.
}

Ved de fleste norske sykehus blir pasienter som har vært involvert i trafikkulykker eller andre høyenergitraumer, håndtert $\mathrm{av}$ et traumeteam ved ankomst til akuttmottaket. Ved St. Olavs hospital aktiveres traumeteamet ca. 10 minutter før pasienten ankommer sykehuset. Teammedlemmene mottar en traumealarm på personsøkeren sin. Hvis det gjenstår mer enn 10 minutter før forventet ankomst, sender AMK først ut et traumevarsel (også et personsøkeroppkall) som en orientering om den forestående pasienten. Selve aktiveringen av traumeteam er lite studert.

Vi har undersøkt data fra det interne traumekvalitetsregisteret ved St. Olavs hospital for 2009 for å finne ut om traumevarselet og timingen av teamaktiveringen påvirket samhandlingen i traumeteamet, målt som tid fra ankomst til røntgen thorax var tatt og oppholdstid i akuttmottaket (1).

Vi fant en signifikant sammenheng mellom timingen av teamaktiveringen og tid til røntgen thorax. Team som ble aktivert mindre enn 10 minutter før ankomst, brukte lengre tid på å få tatt røntgen thorax. Optimalt tidspunkt så ut til å ligge på 10-20 minutter før ankomst. Traumevarselet hadde ingen effekt.

Alle sykehus bør praktisere proaktiv aktivering av traumeteam. Selv om resultatene fra denne studien ikke kan overføres direkte til andre sykehus, gir de en antydning om når teamet bør aktiveres. Alle sykehus som mottar traumepasienter, bør undersøke sin egen teamaktiveringspraksis.

\section{Børge Lillebo}

borge.lillebo@ntnu.no

Norsk senter for elektronisk pasientjournal Norges teknisk-naturvitenskapelige universitet

\footnotetext{
Litteratur

1. Lillebo B, Seim A, Vinjevoll OP et al. What is optimal timing for trauma team alerts? A retrospective observational study of alert timing effects on the initial management of trauma patients. J Multidiscip Healthc 2012; 5: 207-13.
} 